\title{
The ICT Sector in Economic Development of the Countries of Eastern Europe: a Comparative Analysis
}

\author{
MAKSYM DUBYNA \\ Department of Finance, Banking and Insurance, \\ Chernihiv Polytechnic National University, \\ Chernihiv, 14039, UKRAINE \\ NATALIIA KHOLIAVKO \\ Department of Finance, Banking and Insurance, \\ Chernihiv Polytechnic National University, \\ Chernihiv, 14039, UKRAINE \\ ARTUR ZHAVORONOK \\ Department of Public, Corporate Finances and Financial Mediation, \\ Yuriy Fedkovych Chernivtsi National University, \\ Chernivtsi, 58029, UKRAINE \\ YURIY SAFONOV \\ Scientific Institute of Education Content Modernization, \\ Kyiv, 01001, UKRAINE \\ DENYS KRYLOV \\ Department of Finance, Banking and Insurance, \\ Zaporizhzhia National University, \\ Zaporizhzhia, 69061, UKRAINE \\ YULIIA TOCHYLINA \\ Department of Economics and Entrepreneurship \\ Odessa State Academy of Civil Engineering and Architecture, \\ Odessa, 65125, UKRAINE
}

\begin{abstract}
The purpose of the article is to study the impact of the ICT sector on economic development of countries based on the comparative analysis of this sector development in some Eastern European countries. Within the article, economic development of the outlined countries in 2010-2019 was studied and analyzed. The analysis of the impact of the ICT sector on the GDP formation allowed to single out certain groups of countries under this indicator and to identify the characteristics that are inherent to them. Using the correlationregression analysis made it possible to analyze the ICT impact on economies development of Hungary, Bulgaria, Poland, Romania, Slovakia and the Czech Republic. Authors paid a special attention to the study of the influence of various factors on the ICT sector development. Accordingly, an analytical study of the dependence of the ICT sector weight in the GDP of the countries on the following parameters: enterprises that employ ICT specialists; enterprises that provided training to develop/upgrade ICT skills of their personnel; percentage of the ICT personnel in total employment; using Internet for Internet banking, \% of individuals; enterprises who have ERP software package to share information between different functional areas; enterprises selling online (at least $1 \%$ of turnover), $\%$ of enterprises; online purchase in the last 12 months, $\%$ of individuals; enterprises having received orders via computer mediated networks, $\%$ of enterprises. Within the article, the features of the ICT sector development in the COVID-19 context are examined, and it is analyzed how the pandemic has affected the development of this sector in long and short terms. The study showed that the ICT sector today already plays a key role in the development of the national economies. Countries where the sector is developing faster show better performance and economic development.
\end{abstract}


Key-Words: - information and communication technologies, national economy, information technologies, economic development, digitalization, digital services.

Received: July 9, 2021. Revised: December 26, 2021. Accepted: January 10, 2022. Published: January 11, 2022.

\section{Introduction}

Digitalization as one of the main trends in the global economy, transforms all spheres of human activity: from everyday life to professional activities and business. The number of individuals and households using the Internet is growing every year, the range of devices for the Internet access is expanded; there is an increase in the frequency of the computer technology use. Areas of the Internet use by individuals are actively diversified: from traditional sending/receiving e-mails and telephoning/video calls to creating websites, Internet banking and selling goods/services. Innovation information-communication technologies are integrated in the enterprises' activities. According to Eurostat, in the EU-28 $97 \%$ of all enterprises (without financial sector; 10 persons employed or more) have Internet access; 78\% - have websites; 53\% - use any social media; $26 \%$ - pay to advertise on the Internet. The competitiveness of enterprises and national economies is largely determined by the degree of their perception of innovation information and communication technologies, the speed of their modernization and implementation in economic activities of economic entities. In particular, $26 \%$ of enterprises of the EU-28 buy cloud computing services used over the internet; $12 \%$ - analyze big data; $4 \%$ - use 3D printing; $18 \%$ - buy email (as a CC service); $14 \%$ - buy office software; $10 \%$ - buy finance or accounting software applications; $8 \%$ - buy CRMsoftware, etc. (Eurostat). In these conditions, the requirements to digital skills of staff are changing, and enterprises allocate significant funding to organize training courses to develop/upgrade ICT skills of their personnel. With the IT sphere development, the latest technologies, which deepen transformation processes in the national economy, appear. There is a gradual increase in the percentage of the ICT sector in GDP: $4,21 \%$ in Germany, $4,34 \%$ in France, $5,96 \%$ in the United
Kingdom, 3,43\% in Norway, 5,43\% in Finland, $3,48 \%$ in Austria, 3,33\% in Italy. Despite the global economic crisis, parameters of the use of information and communication technologies by enterprises show a growing trend. Moreover, this trend is typical in both developing and developed countries over the past decade.

\section{Literature Review}

The huge role of digitalization in ensuring economic growth is recognized by the countries of the European Union. This is reflected in a number of European initiatives, for example: Digital Europe, Innovation Union, Industrial policy for the globalization era, Going Digital (Making the transformation work for growth and well-being).

Digitalization of socio-economic processes are analyzed by many academics. Most researchers agree on the decisive impact of digitalization on the global economy development. Antikainen et al. [1] note a positive impact of digitalization on the rationalization of resource management. Rachinger et al. [2] highlighted the impact of digitalization on the optimization of business models and their management improving their efficiency. We are impressed by the position of Heavin and Power (2018) [3], Ivashchenko et al. [4], Filippov et al. [5], Vovk et al. [6], Zybareva et al. [7], Mishchuk et al. [8], Tymchenko et al. [9], Tkachuk [10], who emphasize structural changes caused by the economy digitalization.

Digital transformation complicates the technological process and accelerates the innovation cycle $[11 ; 12 ; 13]$. Srai and Lorentz [14] investigate the impact of digitalization on improving supply management. A significant positive impact of digitalization on business is to create the conditions for its internationalization, the spread of start-ups $[15 ; 16 ; 17 ; 18 ; 19]$. Moreover, Alcacer and CruzMachado [20] justify the presence of this impact on the formation of production ecosystems. Fitzgerald et al. [21] note that digital transformation provides an increase in the quality of customer services. According to Paritala et al. [22], due to digitalization, the level of customer orientation of modern business is growing, as the production process in these conditions becomes more adapted to the demands of each consumer, becomes individualized (individual). We hold the same view 
as McDonald and Rowsell-Jones [23] who state that digital transformation creates value and income from digital assets.

Valuable from a scientific and practical point of view are the studies of Solis et al. [24], within which aspects of the customer experience lifecycle are considered. The impact of digitalization on politics, business, public government, and social development are researched in publications of Collin et al. [25], Gimpel and Roglinger [26], Kane et al. [27], Solosich et al. [28], Tulchynska et al. [29], Vovk et al. [30], Viknianska et al. [31]. Aspects of the impact of information and communication technologies on people's lives are revealed in the articles of Martin [31], Stolterman and Forks [33]. Digitalization is making revolutionary changes in the banking system development, modifying both the processes of information processing and the communication of banks with customers $[34 ; 35 ; 36 ; 37 ; 38 ; 39 ; 40$; 41; 42].

Oliner and Sichel [43] investigated historical aspects of the use of information and communication technologies in economic activities and noted the emergence of their positive effects only since the late 1990s. Jorgenson and Stiroh [44] based on the example of the United States argue that the country's economic growth was not driven by technological change, but the replacement of computer equipment. Instead, Jalava and Pohjola [45] argue that information and communication technologies were one of the main factors of economic growth in the United States during this period, and in Finland the above provided economic growth of $0,4 \%$ in the late 1990 s compared to the late 1990s. In 2000, Schreyer [46] researched the contribution of Information and Communication Technology in the development of the G7 Countries. The study of the impact of information and communication technologies on the economic growth of EU countries was contributed by Daveri [47] and Van ark et al. [48] who found a significant lack of European countries from the United States in this parameter. Expanding the sample of analyzed countries, Dewan and Kraemer [49] noticed a significant positive impact of investment in information and communication technologies on developed countries, but noted not statistically significant impact on developing countries. In conclusion, these scientists state that ensuring the investment productivity in information technologies requires investment in the infrastructure, human capital and knowledge-intensive sectors of economy. This conclusion is fully consistent with our vision of the complexity of digitalization processes of the national economy system.

In 2005, research papers appeared that argue that with the Internet access and the spread of information and communication technologies, new industrialized economies are showing higher rates of economic growth [50]. Among the reasons for the lag of developing countries in terms of effective use of information and communication technologies Edquist [51] notes the delay in the introduction of the information technology in the activities of enterprises in these countries. Instead, Antonelli [52] predicted the like hood that developing countries would benefit more from information and communication technologies because, unlike developed countries, they could quickly choose the ICT-oriented paradigm and achieve high economic performance quickly.

The scientific literature presents research results of many scientists who have analyzed the impact of information and communication technologies on economic growth in different periods, various geographic samples, at different economic levels. Researchers use different methodologies, but most conclude that there is a positive contribution of innovative information technologies to the growth of the national economy $[53 ; 54 ; 55 ; 56]$. At the same time, scientists have studied various communication devices, such as mobile phones [57; $58 ; 59 ; 60]$, as well, the broadband infrastructure has been researched $[61 ; 62 ; 63 ; 64 ; 65]$. Valuable for our study is the conclusion of Seo et al. [66] on the existence of a two-way link between the amount of investment in information and communication technologies and the economic growth of the country.

\section{Methodology}

To conduct a thorough study of the ICT development in countries such as Hungary, Bulgaria, Poland, Romania, Slovakia and the Czech Republic, within the article, methods of statistical, index, correlation and regression analysis are used. In particular, the index method was used to identify certain trends of the ICT development in these countries, which allowed to determine the GDP growth rate in Eastern Europe, the volume of products and services in the information sphere. At the same time, the official basis for the study were Eurostat official data.

In addition, in the article, the correlation and regression analysis was used. In particular, the impact of changes in the volume of the ICT sector $n$ changes in GDP was determined through the 
construction of cubic one-factor regression models, such as:

$$
y=\beta_{1} x^{3}+\beta_{2} x^{2}+\beta_{3} x+\beta_{0},
$$

$\mathrm{Y}$ - endogenous variable;

$\mathrm{X}$ - exogenous variable;

$\beta$ - parameters of the calculation model.

At the same time, peculiarities of the impact of individual indicators on the ICT development in the outlined countries were carried out by constructing linear multifactor regression models, such as:

$$
Y=A X+\varepsilon,
$$

$\mathrm{Y}-$ vector of values of the dependent (effective) feature;

$\mathrm{X}$ - matrix of explanatory (factor) features, which has dimension $\mathrm{nXm}$ ( $\mathrm{n}$ - number of observations; $\mathrm{m}$ - number of factors);

A - vector of the model parameters $\left(\alpha_{0}, \alpha_{1}, \alpha_{2}, \alpha_{3} \ldots \alpha_{m}\right)$

$\varepsilon$ - vector of residues.

Therefore, considering the outlined factors and a methodology, the correlation and regression analysis was developed for all countries, which ICT sphere is analyzed in the article, the dependence of the types:

$Y=\alpha_{0}+X_{1} \alpha_{1}+X_{2} \alpha_{2}+X_{3} \alpha_{3}+X_{4} \alpha_{4}+X_{5} \alpha_{5}+X_{6} \alpha_{6}+X_{7} \alpha_{7}+X_{8} \alpha_{8}$

As factor features, the following ones were considered:

X1 - enterprises that employ ICT specialists, \%;

$\mathrm{X} 2$ - enterprises that provided training to develop/upgrade ICT skills of their personnel, \%;

$\mathrm{X} 3$ - percentage of the ICT personnel in total employment, \%;

X4 - using Internet for Internet banking, \% of individuals;

X5 - enterprises who have ERP software package to share information between different functional areas, $\%$;

X6 - enterprises selling online (at least $1 \%$ of turnover), $\%$ of enterprises;

$\mathrm{X} 7$ - online purchase in the last 12 months, $\%$ of individuals;

X8 - enterprises having received orders via computer mediated networks, $\%$ of enterprises.

\section{Results}

Therefore, the study should be started with a general analysis (review) of the trends of economic development in countries such as Hungary,
Bulgaria, Poland, Romania, Slovakia and the Czech Republic. In Fig. 1, information on the GDP volume calculated per capita in these countries and GDP grow rates are presented.

The data of Fig. 1 show that over past ten years in the outlined countries there has been economic development, which is accompanied by periodic declines. However, it can be stated that the level of economic and social security of citizens in the above countries is constantly growing. The analysis of the average GDP growth rate over past ten years shows that the fastest growing economies were in Hungary (the growth index -1,07) and in Romania (the growth index-1,05). Accordingly, the lowest economic growth rates were observed in Slovakia (the growth rate -1,02). However, it should be noted that this is an average indicator of the GDP growth. In some years, the countries have shown more dynamic economic development. However, for example, 2014-2015 for Bulgaria, Poland, Romania, Slovakia and the Czech Republic was a period of short-term slowdown in economic development. That is proved by information presented in Fig.1.

It should be also noted that among all analyzed countries, the fastest growing economy is in Hungary. By the way, economic growth in this country has been stable over the last ten years. From 2010 to the end of 2019, the GDP volume per capita in this country increased from 13,12 thous. euros to 24 thous. euros, which is a significant achievement among other Eastern European countries.

Among the outlined countries, the lowest GDP volume per capita is inherent to Bulgaria (9,58 thous. euros in 2019) and Romania (11,8 thous. euros in 2019). However, these indicators did not increased in average for 30,\% over last ten year, which indicates the development of economy, the formation of a stable basis for further economic development of the above countries.

The development of economy of any country is the result of a number of decisions and numerous measures to build a system of the national economy, which takes place in a constantly changing world, where external factors in relation to any country are objective and have a significant impact on their development.

These processes include informatization, digitalization, which are currently actively developing in the world and change both the 
structure national economies, and the very paradigm of economic development of the countries.

The essence of this change is gradual growth of the role of information sectors of the national economy in economic development, the introduction of modern information technology in the functioning of all enterprises, companies and organizations without exclusion.

The general nature of changes in the world economy in the context of digital transformations leads to changes in approaches to understanding the way to develop economy to maximize positive effects of information economy, which is objectively an integral part of modern society.

\section{GDP volumes calculated per capita, thousands euro}
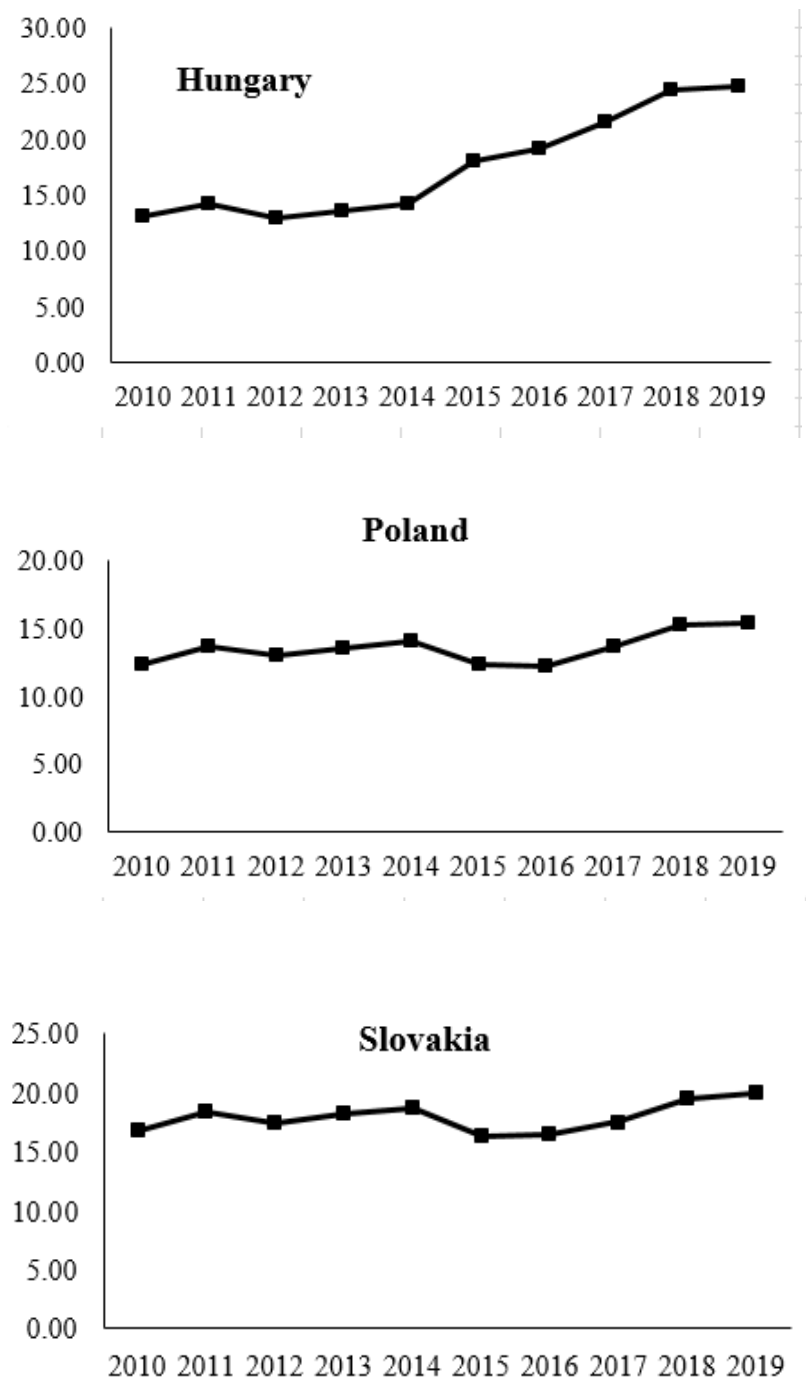
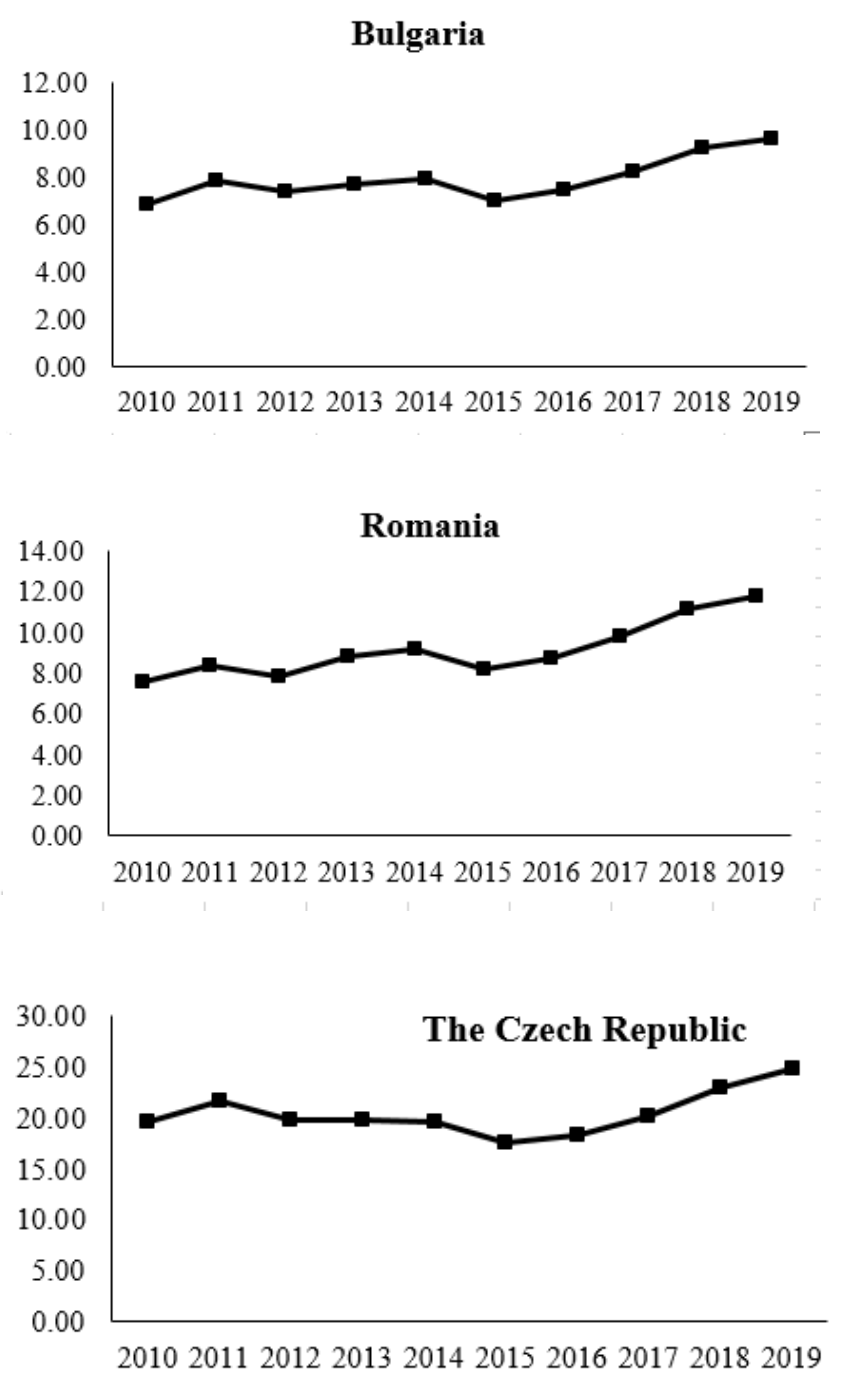

Average GDP growth rate in Eastern Europe 


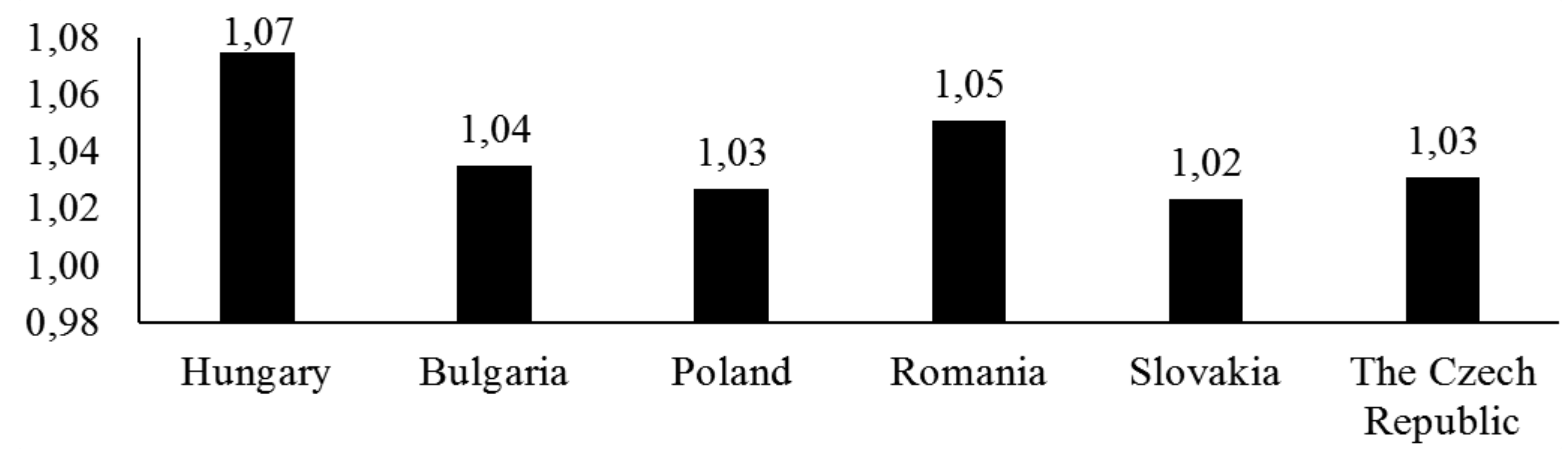

Fig. 1: Information on economic development of the countries of Eastern Europe Source: compiled based on information of the Statistics Service of the European Union, https://ec.europa.eu/eurostat

It is the development of information technology, which is paid today a key role by government of these countries to. New areas formed in accordance to new conditions of economic development, on the one hand, ensure the development and implementation of innovative technologies in all spheres and sectors of economy, and on the other hand, independently create GDP by providing their own services to other businesses. Thus, the ICT development in developed countries today is an integral part, synonymous with economic development. That is the reason to analyze in detail the development of this sphere in Hungary, Bulgaria, Poland, Romania, Slovakia and the Czech Republic. In Fig. 2, information on the volume of products and services of the ICT sector per capita in the outlined countries is presented.

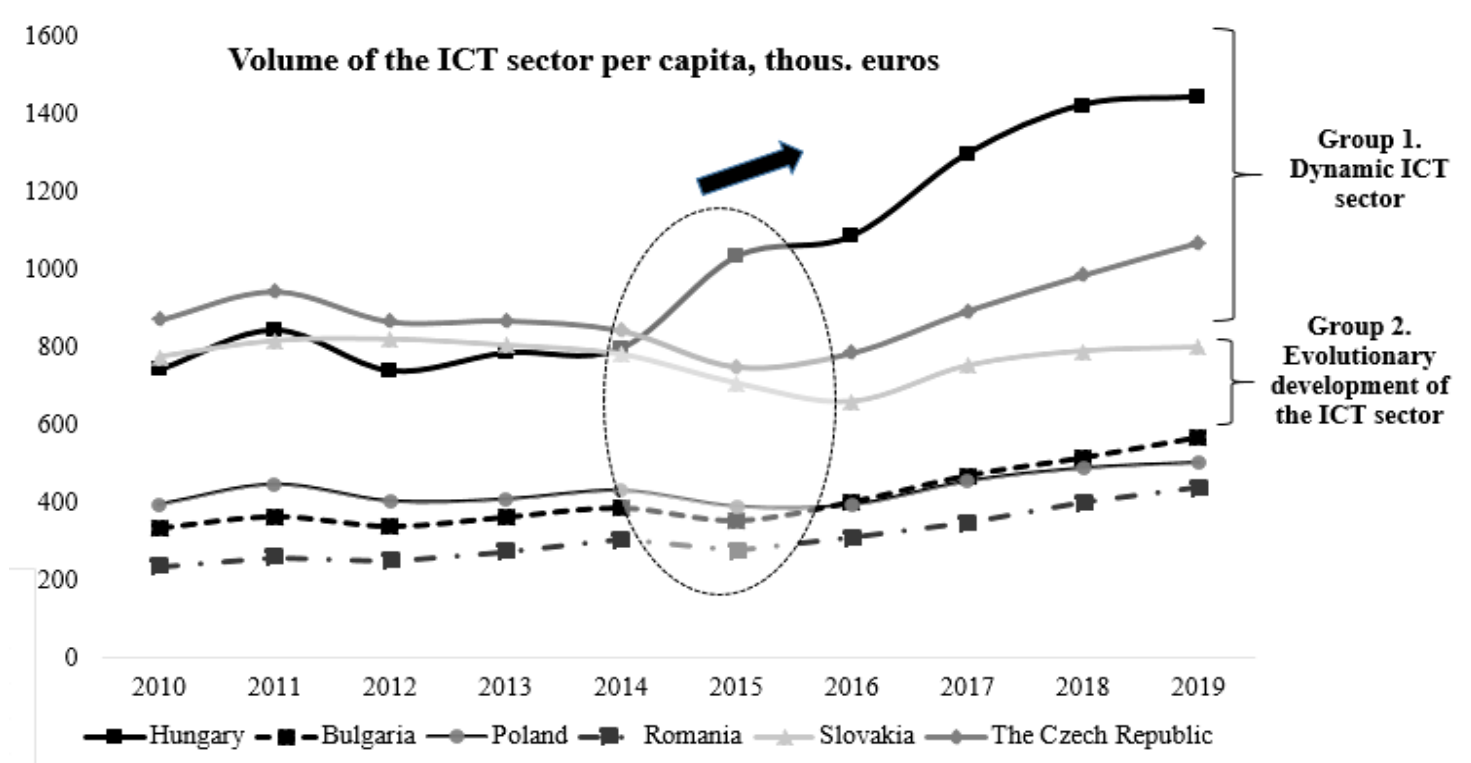

Fig. 2: Volume of products and services of the ICT sector per capita, thous. euros

Source: compiled by the authors based on information of The Statistic Service of the European Union, https://ec.europa.eu/eurostat

Analyzing the information in Fig.2, after making appropriate calculations, according to the level of the ICT sector development, the outlined countries were divided into two groups:
1) countries of Eastern Europe with dynamic ICT development, which include Hungary, the Czech Republic and Slovakia. This group of countries is characterized by rapid development of the given sector, total introduction of innovations in all spheres of society. 
The pace of development of the ICT sector in Hungary is of particular note. If in 2010, the volume of products, services and goods produced within this sector made 7,44 billion euros, then in 2019 - 14,16 billion euros, that is it has actually increased twice. Actually, it is not possible to provide this development without appropriate support of the state. In these countries, the governments paid special attention to the ICT development, that contributed to the activation of economic activity in the above sector.

2) countries of Eastern Europe with evolutionary ICT development - the countries where gradual development of the outlined sector takes place, which is due mainly by their economic development. This group includes Bulgaria, Poland and Romania. Governments of these countries today pay important attention to the ICT sector development; in particular, strategies for this sector development were adopted. At the current stage, the growth rate of ICT products and services per capita in the countries of this group indicates active development of such technologies.

It should be noted that 2014-2015 became crucial for the ICT sector development. Until now, the ICT sector development in all

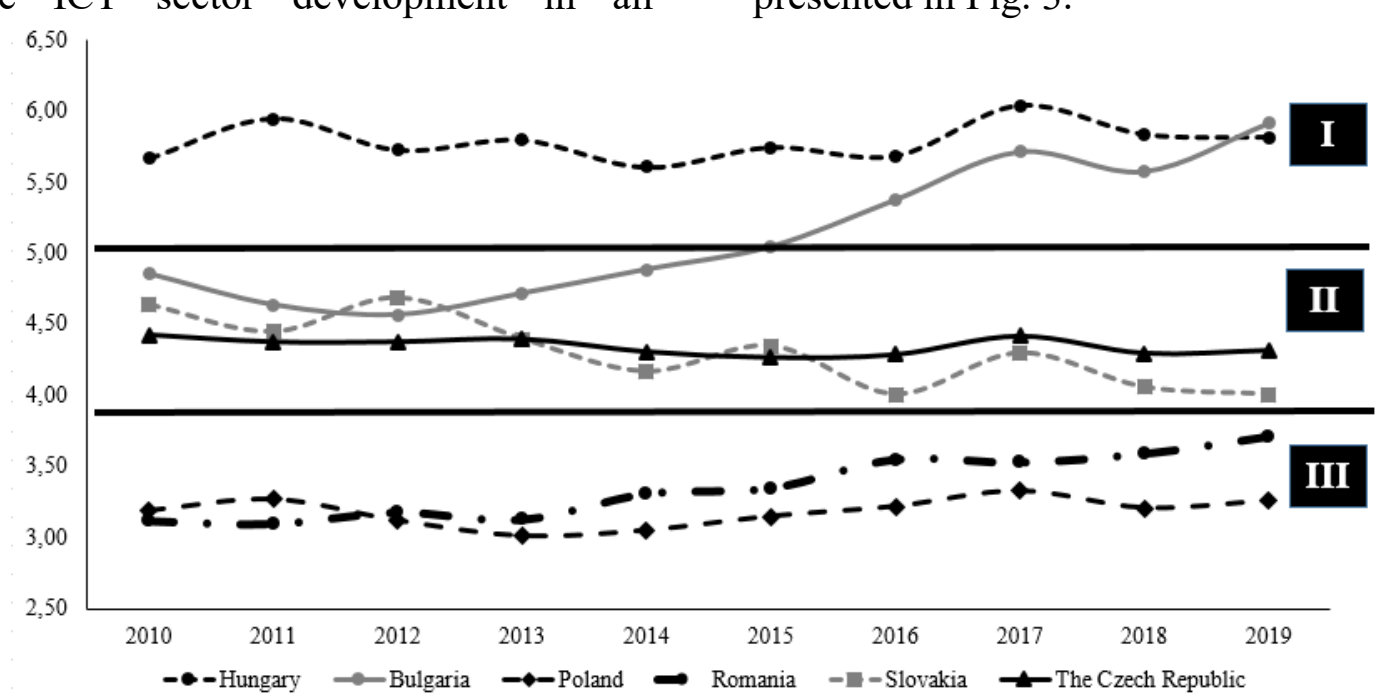

Fig. 3: Share of the ICT sector in the GDP volume, \%

Source: compiled by the authors based on information of The Statistic Service of the European Union, https://ec.europa.eu/eurostat

Considering the data in Fig. 3, it can be stated that for different countries the role of the ICT sector is differs for today, however, one can observe simultaneous and constant growth countries was observed at a fairly equal level for each of them, the growth rate remained stable. Staring from 2015, active development of the ICT sector in all countries (Fig.1) can be observed, which is connected with increased attention to digitalization on the part of authorities (the EU level) and leading enterprises and organizations (the macro economic level). For instance in 2015, A Digital Single Market Strategy for Europe was adopted, in October 2015 in Lisbon (Portugal) a large-scale event "ICT 2015 Innovate, Connect, Transform" with more than 6000 participants was conducted, there were 2 European Commissioners, more than 120 speakers who spoke at 15 panel sessions. Moreover, until 2015, there had been practical implementation of A Digital Agenda for Europe. According to The Global Information Technology Report (ICTs for Inclusive Growth) in 2015 under The Readiness Index, Poland was included to top-50 countries of the world, and Romania demonstrated a significant jump raising its positions by 12 points (ranked 63rd according to this index). The role of the ICT sector in the GDP formation of the countries should be analyzed. Relevant information is presented in Fig. 3. 
Group I - countries with the biggest share of the ICT sector. This group includes Hungary, where the development of the outlined sector is the most rapid. The ICT sector is also beginning to play an active role in the GDP growth in Bulgaria. As of the end of 2019, the share of the ICT sector in GDP of this country made $5,92 \%$, which is higher than in Hungary $(5,82)$.

Group II - countries with stable share of the ICT sector in the volume of their GDP. This group includes the Czech Republic and Slovakia. It should be noted that the decrease of the outlined share from $4,43 \%$ in 2010 to $4,32 \%$ in 2019 can be observed. However, during 2010-2019, GDP of the Czech Republic increased nearly for $30 \%$, which states about the growth of the ICT sector in the country. Similar situation can be observed in Slovakia. In this country over the last ten years, the share of the ICT sector in GDP decreased from $4,64 \%$ to $4,01 \%$, but at the same time, GDP of the country increased nearly for 20\%, which proves the ICT sector development.

Group III - countries with active development of the ICT sector and its gradual increase in the GDP role. This group includes such countries as Poland, and Romania. In these countries, we can still see a small percentage of the ICT sector in GDP. However, as it is proved by the data in Fig.3, this situation is gradually changing. Starting from 2015, part of the outlined sector is constantly growing. If in 2014, its share in GDP of Poland made 3,05\%, then in $2019-3,26 \%$. Similar situation can be observed in Romania. In $2013-3,13 \%$, and in $2019-3,71 \%$.

In addition, within the article, the correlation-regression analysis to build an understanding of the ICT impact on the GDP development is used, and econometric models of the relationship between changes in the pace of the ICT implementation and GDP growth in Hungary, Bulgaria, Poland, Romania, Slovakia and the Czech Republic are built. Relevant calculations are presented in Fig. 4. At the same time, much attention is paid to the need to stimulate the ICT sector development, the formation of conditions for stable development of small businesses in the field of information and communication technologies. It is clear that the ICT sector and its efficiency are becoming an integral part by ensuring the country's competitiveness in the global economic space.

It should be noted that the issues of the ICT sector development are becoming especially important today given the objectivity of digitalization and informatization processes, it is also necessary to understand how to ensure the ICT sector growth, on which factors its stable orientation depends.

To this end, we conducted a study of the determination of individual factors of different nature for the ICT sector development in each of the countries: Hungary, Bulgaria, Poland, Romania, Slovakia and the Czech Republic. 


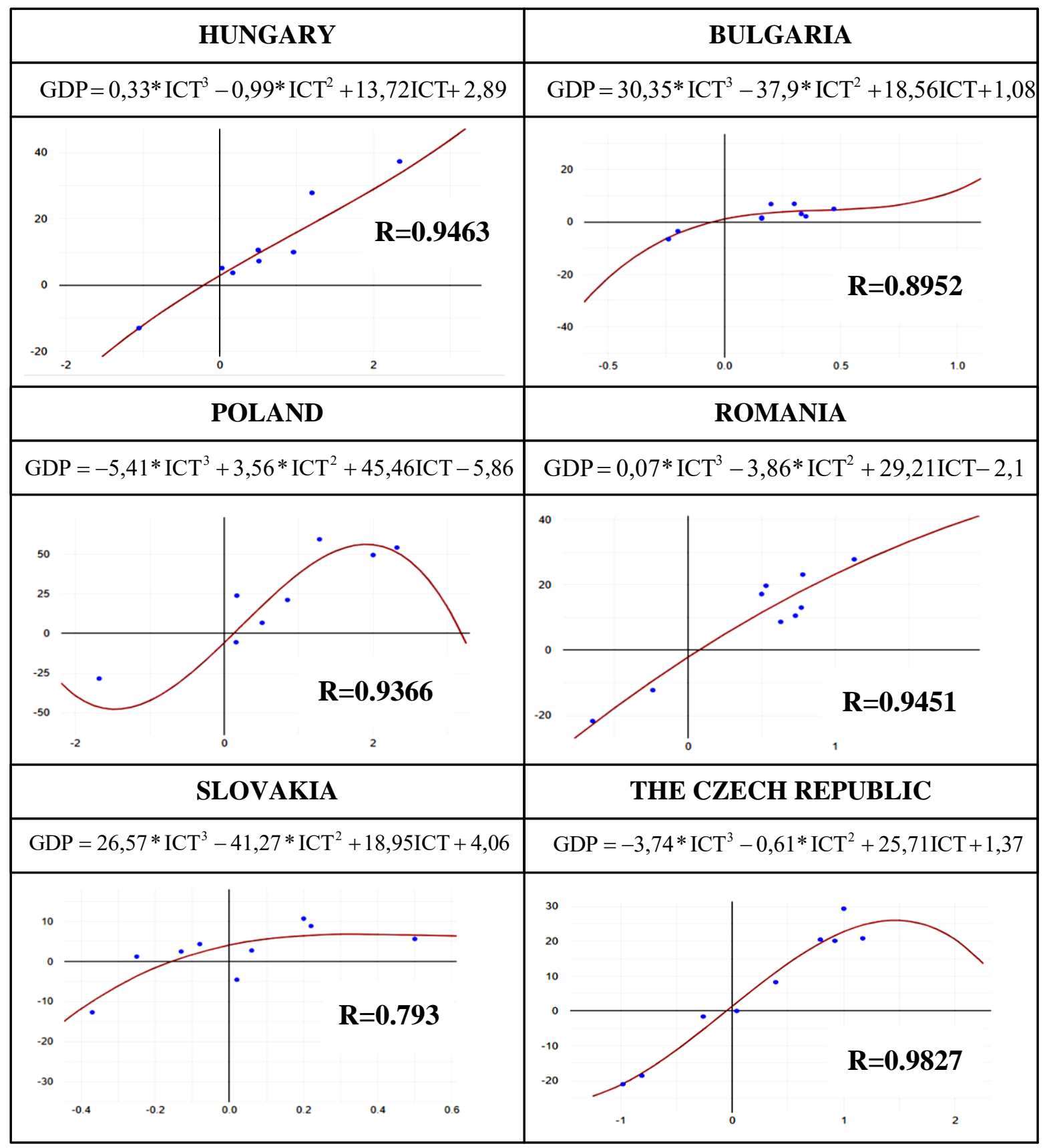

Fig. 4: Impact of the change of the ICT sector on the GDP change

Source: compiled by the authors based on information of The Statistic Service of the European Union, https://ec.europa.eu/eurostat

To carry out the outlined study, a methodology of the correlation-regression analysis was used, and linear multifactor regression models were built, which allowed to determine algebraic equations of the relationship between the share of the ICT sector in GDP and individual factors. The results of the conducted modeling are presented in Fig. 5. 


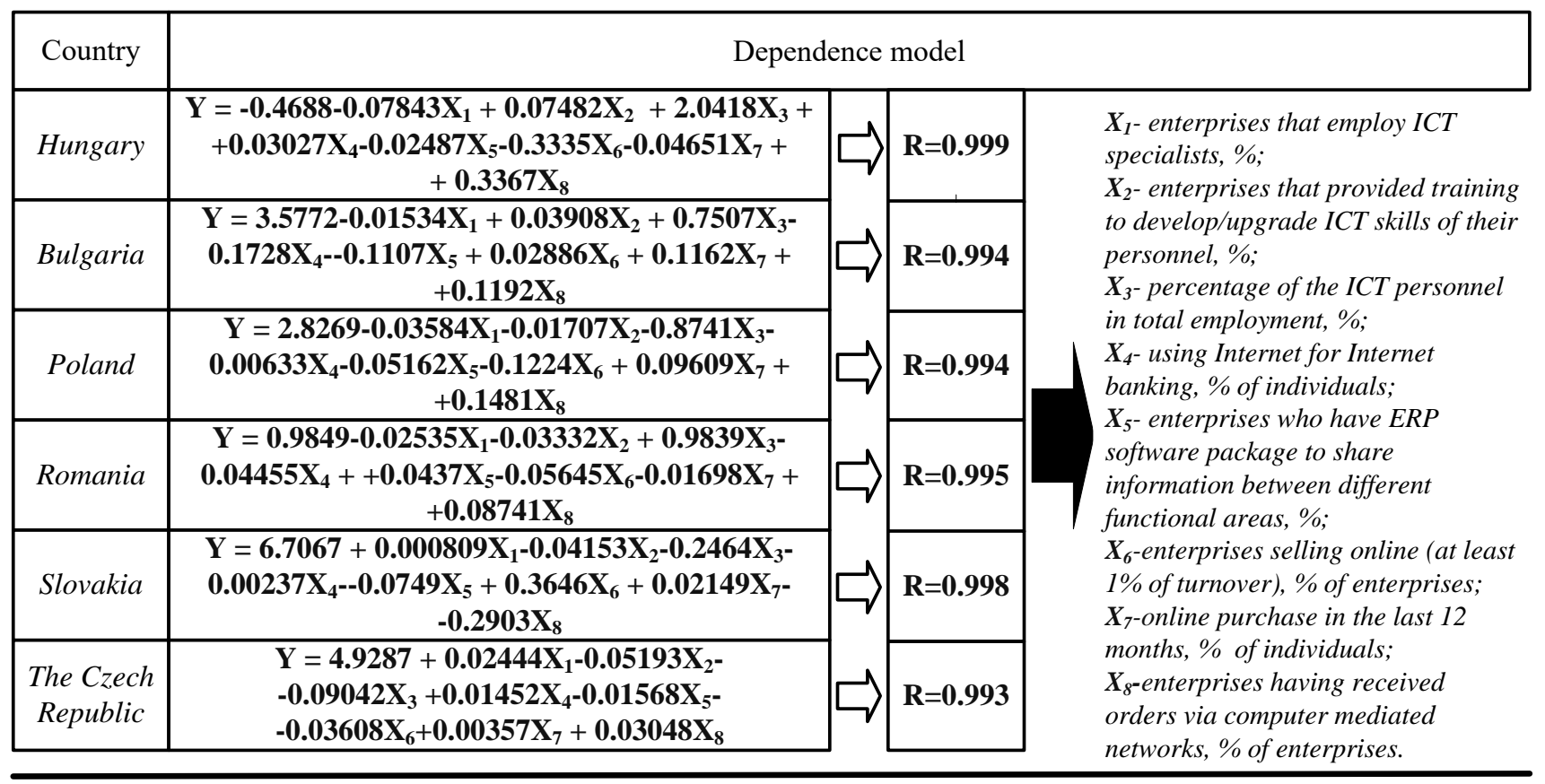

\begin{tabular}{|c|c|c|c|c|c|c|c|c|}
\hline Country & $\mathbf{X}_{\mathbf{1}}$ & $\mathbf{X}_{\mathbf{2}}$ & $\mathbf{X}_{\mathbf{3}}$ & $\mathbf{X}_{\mathbf{4}}$ & $\mathbf{X}_{\mathbf{5}}$ & $\mathbf{X}_{\mathbf{6}}$ & $\mathbf{X}_{\mathbf{7}}$ & $\mathbf{X}_{\mathbf{8}}$ \\
\hline Hungary & -0.07843 & $\mathbf{0 . 0 7 4 8 2}$ & $\mathbf{2 . 0 4 1 8}$ & $\mathbf{0 . 0 3 0 2 7}$ & $\mathbf{- 0 . 0 2 4 8 7}$ & $\mathbf{- 0 . 3 3 3 5}$ & $\mathbf{- 0 . 0 4 6 5 1}$ & $\mathbf{0 . 3 3 6 7}$ \\
\hline Bulgaria & -0.01534 & 0.03908 & 0.7507 & -0.1728 & -0.1107 & 0.02886 & $\mathbf{0 . 1 1 6 2}$ & $\mathbf{0 . 1 1 9 2}$ \\
\hline Poland & -0.03584 & -0.01707 & -0.8741 & -0.00633 & -0.05162 & -0.1224 & $\mathbf{0 . 0 9 6 0 9}$ & $\mathbf{0 . 1 4 8 1}$ \\
\hline Romania & -0.02535 & -0.03332 & $\mathbf{0 . 9 8 3 9}$ & -0.04455 & $\mathbf{0 . 0 4 3 7}$ & -0.05645 & -0.01698 & $\mathbf{0 . 0 8 7 4 1}$ \\
\hline Slovakia & $\mathbf{0 . 0 0 0 8 0 9}$ & -0.04153 & -0.2464 & -0.00237 & -0.0749 & $\mathbf{0 . 3 6 4 6}$ & $\mathbf{0 . 0 2 1 4 9}$ & -0.2903 \\
\hline The Czech Republic & $\mathbf{0 . 0 2 4 4 4}$ & -0.05193 & -0.09042 & $\mathbf{0 . 0 1 4 5 2}$ & -0.01568 & -0.03608 & $\mathbf{0 . 0 0 3 5 7}$ & $\mathbf{0 . 0 3 0 4 8}$ \\
\hline
\end{tabular}

Fig. 5: Models of the dependence of the share of the ICT sector in GDP of countries on other parameters Source: compiled by the authors based on information of The Statistic Service of the European Union, https://ec.europa.eu/eurostat

By analyzing the data presented in Fig. 5, we can make the following conclusions. First, the development of the ICT sector in all countries was positively affected by the percentage of enterprises that received orders via the Internet, which indicates a gradual change in traditional marketing systems of these enterprises and allows for active development of online orders and related software. Given significant pace of the economy digitalization of all countries, it is logical that the outlined parameter increases and has a positive impact on the outlined sector development. In addition, the functioning of the ICT sector in virtually all countries was positively affected by the growth of enterprises that sell their own goods and services via the Internet (at least 1\% from the turnover). This indicator exclusively in Romania and Hungary does not pay such key meaning in the ICT sector development compared to other countries.

Thus, the ICT sector depends on many factors, both external (global trends, international information services market), and internal ones (political stability of countries, economic cycle phase, inflation rate, level of business innovation, etc.), which determines this sector as complex economic objective knowledge. However, the inseparability of this sector from economic development, according to the study, is objective.

\section{Discussion}

The COVID-19 coronavirus pandemic has shaken the world affecting positive dynamics of the global economy. In our study, we deliberately limited ourselves to analyzing the data of 2019 in order to prevent distortion of information and ensure the reliability of the 
results obtained on the identified trends, patterns and casual relationships. National economies of the number of countries have experienced powerful adverse effects of the pandemic and quarantine restrictions in 2020. In this context our research correlates with the results and conclusions formulated in research papers $[67 ; 68 ; 69 ; 70 ; 71 ; 72 ; 73 ; 74]$. The decline in oil prices and major indices of the world stock exchanges in the United Kingdom, Japan and the United States had a negative impact on the development of national economies. Some countries, which revenues on a large extent depend on the tourism industry, have been significantly affected by restrictions on crossing state borders, the suspension of flights and the operation of hotels and restaurants. The challenges of the pandemic to the national economies outlined above are deeply analyzed and substantiated in the work of S. Roy [75], and study of de Vet J.M. et al. [76].

Manifestations of the pandemic impact on the economies of the countries analyzed in the article (Hungary, Bulgaria, Poland, Slovakia, The Czech Republic) are the decline in real GDP, rising unemployment, decrease of foreign trade, reduction of incomes, and accordingly, the level of citizens' solvency, narrowing of social assistance programs, as well as the bankruptcy of a number of small and medium enterprises. Referring the last thesis, the results of the research by Markovic et al. [77] should be presented, with which we fully agree. In particular, these scientists argued that the COVID-19 crisis had a negative impact on small businesses in the spheres of consulting, entertainment (event-management), construction and architecture, financial services, marketing and advertising. At the same time, we fully support the view of Markovic et al [77] that the COVID-19 pandemic has formed prerequisites for the activation of the development of small and medium business in the e-commerce, IT-services, R\&D services spheres.

As it is evidenced by official statistics (Eurostat), at the background of the growing unemployment of population and reducing the employment level of the youth in the pandemic period, the increase of the employment indicator of ICT-specialists in Bulgaria can be observed (from 3,1\% of employed in 2019 to $3,3 \%$ in 2020), The Czech Republic (from 4,0\% to $4,2 \%$ ), Hungary (from $3,4 \%$ to Poland (from $3,1 \%$ to $3,4 \%$ ), Romania (from $2,3 \%$ to $2,4 \%$ ), Slovakia (from $3,7 \%$ to $4,2 \%$ ). Attention should be also paid to the employment in high - and medium - high technology manufacturing sectors and knowledge - intensive service sectors, as in the 2019-2020 period they showed relatively small declines in employment, and in Bulgaria and Slovakia there was even an increase in this indicator by $0,1 \%$ and $0,3 \%$ accordingly (Eurostat).

In the analyzed context, we consider appropriate to present the following facts: during 2019-2020, the enterprises' total turnover from e-commerce sales has grown for $5 \%$ in Romania, $2 \%$ in Bulgaria, and it was on comparatively high level in the Czech Republic (more than $30 \%$ of turnover of enterprises) and in Hungary and Slovakia (more than $20 \%$ of turnover of enterprises). As it can be seen from Table 3, The International Monetary Fund gives quite optimistic forecasts concerning the national economies development of the analyzed countries of the EU in 2021-2022, when forbearance of quarantine conditions and wide vaccination of population from acute COVID-19 respiratory diseases is envisaged.

However, achievements of the predicted indicators presented in Table 1 is possible only on the basis of active digitalization of business and management, development of information literacy of population, increasing the level of innovation activity of enterprises and establishment of favorable partnership of the government, business, universities and the public.

Table 1. Prognosis of the International Monetary Fund for 2021-2022, annual \% change

\begin{tabular}{|l|c|c|c|c|c|c|c|c|}
\hline \multirow{2}{*}{ Country } & \multicolumn{2}{|c|}{ Real GDP } & \multicolumn{2}{c|}{ Consumer Prices } & \multicolumn{2}{c|}{ Current Account Balance } & \multicolumn{2}{c|}{ Unemployment } \\
\cline { 2 - 9 } & 2021 & 2022 & 2021 & 2022 & 2021 & 2022 & 2021 & 2022 \\
\hline Bulgaria & 4.4 & 4.4 & 1.0 & 2.0 & 1.4 & 1.2 & 4.8 & 4.4 \\
\hline Czech Republic & 4.2 & 4.3 & 2.3 & 2.0 & 0.9 & 0.1 & 3.4 & 3.2 \\
\hline
\end{tabular}




\begin{tabular}{|l|c|c|c|c|c|c|c|c|}
\hline Hungary & 4.3 & 5.9 & 3.6 & 3.5 & -0.4 & -0.3 & 3.8 & 3.5 \\
\hline Poland & 3.5 & 4.5 & 3.2 & 2.5 & 2.0 & 1.3 & 4.9 & 4.5 \\
\hline Romania & 6.0 & 4.8 & 2.8 & 2.1 & -5.0 & -4.7 & 4.9 & 4.9 \\
\hline Slovakia & 4.7 & 4.4 & 1.2 & 1.9 & -1.2 & -2.0 & 7.3 & 6.7 \\
\hline
\end{tabular}

Source: The International Monetary Fund, https://www.imf.org

Judging from the results of the analysis carried out in the framework of this article, we can state that the COVID-19 pandemic in Eastern Europe countries has neutral or even often positive impact on the ICT sector development. Having come to this conclusion, we should note our solidarity with the position of Evans C. [78] who substantiated that the ICT sector provides a set of tools and resources necessary for business and national economies in new isolation, social distancing and other quarantine restrictions. Proving her position, Evans C. [78] explored three elements of the pandemic's impact on the ICT sector, namely: accelerated digital transformations; growing importance of the information technology in economy and society; deepening inequalities in the access to the advanced technologies use. This comprehensive approach to the analysis used in the research of Evans C. (2020), in our point of view, is the most appropriate in today's turbulent socio-economic environment with a high degree of uncertainty and unpredictability. We believe that this approach should be based on the principles of flexibility, dynamism and efficiency to ensure the collection of rapidly updated information and its analysis in real time.

\section{Conclusion}

Modern information and communication technologies are a powerful factor in the national economies growth; in scientific literature, a positive impact of these technologies on the pace of economic growth and the competitiveness of the countries in the global dimension is proved. In this article, by using approbated research tool, this thesis is substantiated related the countries of Eastern Europe (Bulgaria, The Czech Republic, Hungary, Poland, Romania, Slovakia) in the 2010-2019 period. Within the article the authors divided the analyzed countries into two groups according to the level of the ICT sector development: 1) countries of Eastern Europe with dynamic ICT development (Hungary, the Czech Republic, Slovakia) - characterized by rapid development of the ICT sector, total introduction of innovations in all spheres of society; 2) countries of Eastern Europe with evolutionary ICT development (Bulgaria, Poland and Romania) - characterized by gradual development of the outlined sector, developed strategies for ICT sector, high growth rate of ICT products and services per capital.

The conducted research allowed identification of three groups of Eastern Europe countries depending on the share of the ICT sector in GDP of the country:

Group I - countries with the biggest share of the ICT sector (Hungary, Bulgaria) - the development of the ICT sector is the most rapid; the ICT sector is beginning to play an active role in the GDP growth; Group II - countries with stable share of the ICT sector in the volume of GDP (the Czech Republic, Slovakia) - the decrease of the outlined share from $4,43 \%$ in 2010 to $4,32 \%$ in 2019 ;

Group III - countries with active development of the ICT sector and its gradual increase in the GDP role (Poland, Romania) - small percentage of the ICT sector in GDP; in the same time this situation is gradually changing starting from 2015 .

It is emphasized by the authors that the COVID-19 pandemic and quarantine restrictions caused by it destroyed the usual manner of socio-economic processes both in the regional and national, and interstate levels. In these new conditions of economic activity, economic entities of some countries of the world faced with a very high level of uncertainty, strict restrictions for business, as well as the reduction of the population solvency.

It is noted by the authors that the pandemic led not only to problems for the national economies (growing unemployment, production decrease, GDP reduction, devaluation of the national currency, bankruptcy of the enterprises., etc.), but it has formed additional preconditions for the IT sector development and the business digitalization. Companies that were able to transfer their activities and communication with consumers online, primarily due to active introduction of information and communication technologies, managed to maintain their competitive positions. The presence of a holistic digital component in the development strategy, the formed e-skills of the staff, the dynamism of updating information technology and 
mastering digital tools of the interaction with stakeholders gave the above companies additional competitive advantages. In addition, it should be emphasized that digital transformation of business has provided it with high resilience to the challenges of the COVID-19 pandemic. The only exception was the period of the "first wave" of quarantine restrictions, lockdown, when there was a certain decline in the development of enterprises in the ICT sector, but compared to other sectors, this decline was insignificant. After a fairly rapid adaptation to new conditions of the operation, digital enterprises began to increase the pace of development and increase the level of profitability of their activities.

\section{References:}

[1] M. Antikainen, T. Uusitalo \& P. KivikytöReponen, "Digitalisation as an Enabler of Circular Economy", Procedia CIRP, 73, pp. 45-49, 2018. https://doi.org/10.1016/j.procir.2018.04.027

[2] M. Rachinger, R. Rauter, C. Müller, W. Vorraber \& E. Schirgi, "Digitalization and its influence on business model innovation", Journal of Manufacturing Technology Management, 30 (8), pp. 1143-1160, 2018. https://doi.org/10.1108/JMTM-01-2018-0020

[3] C. Heavin \& D. J. Power, "Challenges for digital transformation-towards a conceptual decision support guide for managers", Journal of Decision Systems, 27 (sup 1), pp. 38-45, 2018.

[4] A. I. Ivashchenko, \& N. S. Orlova, "Comparative analysis of some EU and EU associated countries to identify the phenomenon of business development in postsocialist countries", Economic Annals-XXI, 163(1-2(1)), pp. 22-25, 2017. https://doi.org/10.21003/ea.V163-04

[5] V. Filippov, O. Malin, S. Filyppova, Y. Kovtunenko \& L. Voloshchuk, "Sustainable development entrepreneurship formation: System-integrated management tools", International Conference on Sustainable, Circular Management and Environmental Engineering (ISCMEE 2021): E3S Web of Conferences, Vol. 255. 8 p. https://doi.org/10.1051/e3sconf/202125501049

[6] V. Vovk, Y. Zhezherun, O. Bilovodska, V. Babenko \& A. Biriukova, "Financial monitoring in the bank as a market instrument in the conditions of innovative development and digitalization of economy", Management and Legal Aspects of the Risk-Based Approach,
31(4), $\quad$ pp. $\quad 559-570, \quad 2020$. https://doi.org/10.22068/ijiepr.31.4.559

[7] O. Zybareva, I. Kravchuk, Y. Pushak, L. Verbivska \& O. Makeieva, "Economic and Legal Aspects of the Network Readiness of the Enterprises in Ukraine in the Context of Business Improving", Estudios de economía aplicada, 39(5), 2021. https://doi.org/10.25115/eea.v39i5.4972

[8] I. Mishchuk, O. Zinchenko, D. Zinchenko, P. Dariusz, A. Pohrebniak, "Differences in the Assessment of Economic Security of Personnel and Security of Enterprise Staff Interests", WSEAS Transactions on Environment and Development, 16, pp. 454-463, 2020.

[9] O. Tymchenko, Yu. Sybirianska, A. Abramova, "The Approach to Tax Debtors Segmentation", Ikonomicheski Izsledvania, 28(5), pp. 103-119, 2019.

[10] I. Tkachuk, "Asset operations of Ukrainian banks on the current stage of banking system development", Banks and Bank Systems, 12(11), pp. 119-127, 2017.

[11] B. A. Latos, M. Harlacher, F. Burgert, V. Nitsch, P. Przybysz \& S. M. Niewohner, "Complexity Drivers in Digitalized Work Systems: Implications for Cooperative Forms of Work", Advances in Science. Technology and Engineering Systems Journal, 3(5), pp. 171-185, 2018. https://doi.org/10.25046/aj030522

[12] A. Ivashchenko, Y. Polishchuk, "Machine learning in estimating of SMEs investment potential in Ukraine", CEUR Workshop Proceedings, 2105, 77-93, 2018.

[13] A. Ivashchenko, Y. Kovalenko, O. Hubanov, T. Hubanova, I. Lutsenko, A. Fialkovska, "Digital Tools in Cross-Cultural Analysis of Sme Financial State Support in the Conditions of Pandemic Crisis", Journal of Information Technology Management, 13, pp. 142-162, 2021.

[14] J. S. Srai \& H. Lorentz, "Developing design principles for the digitalization of purchasing and supply management", Journal of Purchasing and Supply Management, 25(1), pp. 78-98, 2019. https://doi.org/10.1016/j.pursup.2018.07.001

[15] M. Neubert, "The impact of digitalization on the speed of internationalization of lean global startups", Technology Innovation Management Review, 8(5), pp. 44-54, 2018. http://doi.org/10.22215/timreview/1158

[16] O. Zybareva, L. Verbivska, I. Lopashchuk, O. Kalaman, T. Drkach, T. Smentyna, 
"Strategically-Oriented Enterprise Management through Information Systems", International Journal of Recent Technology and Engineering, 8(2), pp. 3014-3017, 2019.

[17] K. Shaposhnykov, A. Abramova, A. Zhavoronok, P. Liutikov, I. Skvirskyi \& O. Lukashev, "Ecosystem of VAT Administration in E-Commerce: Case of the Eastern Europe Countries", Estudios de economía aplicada, 39(5),

2021.

http://dx.doi.org/10.25115/eea.v39i5.4909

[18] K. Shaposhnykov, O. Kochubei, O. Grygor, N. Protsenko, O. Vyshnevska, \& A. Dzyubina, "Organizational and Economic Mechanism of Development and Promotion of IT Products in Ukraine", Estudios de economía aplicada, 39(6), 2021. https://doi.org/10.25115/eea.v39i6.5264

[19] S. Shkarlet, \& M. Dubyna "Features of the cognitive approach application to the essence of the financial services market identification", Economic Annals-XXI, 158(3-4(2)), 70-74, 2016. https://doi.org/10.21003/ea.V158-16

[20] V. Alcácer, V. Cruz-Machado, "Scanning the industry 4.0: A literature review on technologies for manufacturing systems", Engineering Science and Technology, an International Journal, 22(3), pp. 889-919, 2019.

https://doi.org/10.1016/j.jestch.2019.01.006

[21] M. Fitzgerald, N. Kruschwitz, D. Bonnet \& M. Welch, "Embracing Digital Technology: A New Strategic Imperative", MIT Sloan Management Review, Research Report, 2013. URL:

https://sloanreview.mit.edu/projects/embracingdigital-technology

[22] P. K. Paritala, S. Manchikatla \& P. K. Yarlagadda, "Digital manufacturingapplications past, current, and future trends", Procedia engineering, 174, pp. 982-991, 2017. https://doi.org/10.1016/j.proeng.2017.01.250

[23] M. McDonald \& A. Rowsell-Jones, "The Digital Edge: Exploiting Information \& Technology for Business Advantage", Gartner Inc, 2012.

[24] B. Solis, R. Lieb \& J. Szymanski, "The 2014 State of Digital Transformation", Altimeter Group, 2014.

[25] J. Collin, K. Hiekkanen, J.J. Korhonen, M. Halen, T. Itälä \& M. Helenius, "IT Leadership in transition - the impact of digitalization on Finnish organizations", Aalto University publication series SCIENCE + TECHNOLOGY, 7, Aalto University, 2015.
URL: http://urn.fi/URN:ISBN:978-952-606243-3

[26] H. Gimpel, \& M. Röglinger, "Digital Transformation: Changes and Chances-Insights Based on an Empirical Study", University of Augsburg, Augsburg, 2015. URL: https://www.fim-

rc.de/Paperbibliothek/Veroeffentlicht/542/wi542.pdf

[27] G. Kane, D. Palmer, A. Phillips, D. Kiron \& N. Buckley, "Strategy, not Technology, Drives Digital Transformation", MIT Sloan Management Review and Deloitte University Press, 2015.

[28] O. Solosich, O. Popelo, O. Nusinova, M. Derhaliuk \& S. Tulchynska, "Ensuring economic security of regions as a potentialforming space in the conditions of intellectualization", Academy of Entrepreneurship Journal, 27(6), pp. 1-8, 2021. https://doi.org/1528-2686-27-6-617

[29] S. Tulchynska, O. Popelo, O. Garafonova, I. Yaroshenko \& I. Semyhulina, "Modeling the influence of innovative factors on sustainable development of regions in the context of digitalization", Journal of Management Information and Decision Sciences, 4(8), pp. 18, 2021. https://doi.org/1528-2635-24-8-367

[30] V. Vovk, A. Denysova, K. Rudoi \& T. Kyrychenko, "Management and legal aspects of the symbiosis of banking institutions and fintech companies in the credit services market in the context of digitization", Estudios de economía aplicada, 39(7), 2021. https://doi.org/10.25115/eea.v39i7.5013

[31] A. Viknianska, D. Kharynovych-Yavorska, M. Sahaidak, A. Zhavoronok, \& V. Filippov, "Methodological approach to economic analysis and control of enterprises under conditions of economic systems transformation", Naukovyi Visnyk Natsionalnoho Hirnychoho Universytetu, 4, pp. 150-157, 2021. https://doi.org/10.33271/nvngu/2021-4/150

[32] A. Martin, "Digital Literacy and the Digital Society", Digital Literacies: Concepts, Policies, and Practices, Peter Lang, New York, pp. 151-176, 2008.

[33] E. Stolterman \& A.C. Fors, "Information Technology and the Good Life. In: Kaplan B., Truex D.P., Wastell D., Wood-Harper A.T., DeGross J.I. (eds)", Information Systems Research. IFIP International Federation for Information Processing, 143, pp. 687-692, 
2004. https://doi.org/10.1007/1-4020-80956_45

[34] S. Carbó-Valverde, "The impact of digitalization on banking and financial stability", Journal of Financial Management, Markets and Institutions, 1, pp. 133-140, 2017.

[35] S. Tulchynska, O. Popelo, O. Vovk, B. Dergaliuk, I. Kreidych, \& T. Tkachenko, "The Resource Supply of Innovation and Investment Strategies of the Microeconomic Systems Modernization in the Conditions of Digitalization", WSEAS transactions on environment and development, 17, pp. 819-828, 2021. https://doi.org/10.37394/232015.2021.17.77

[36] S. Shkarlet, N. Kholiavko \& M. Dubyna, "Territorial reform in the system of strategic management of energy-economic and information spheres of the state", Economic Annals-XXI, 5-6, pp. 103-107, 2015.

[37] K. D. S. Yu, K. B. Aviso, J. R. Santos, \& R. R. Tan, "The Economic Impact of Lockdowns: A Persistent Inoperability Input-Output Approach", Economies, 8(4), pp. 1-14, 2020. https://doi.org/10.3390/economies 804010

[38] J. M. Cardona, J. Andreu, S. Cano, "A new risk history: The Eastern Europe case", WSEAS Transactions on Business and Economics, 11, pp. 188-198. 2014.

[39] O. Kulynych, O. Kurylina, N. Serdiuk, S. Bashlai, O. Nesterenko, P. Trachuk, "Protection of Economic Rights in Eastern European Countries", WSEAS Transactions on Business and Economics, 18, pp. 803-814, 2021.

[40] O. V. Zybareva, P. I. Shylepnytskyi, L. V. Verbivska, S. I. Belei, I. O. Parubchak, "Local partnership as a tool for stimulating the development of rural areas of Ukraine", Journal of the National Academy of Legal Sciences of Ukraine, pp. 27(4), 121-133, 2020.

[41] I. Kalenyuk, L. Tsymbal, M. Fedyshyn, "Methodical principles of estimationof intellectual leadership of the global economy actors", Iconomicheski Izsledvania, 28(6). pp. 74-87, 2019.

[42] R. Biloskurskyy, A. Verstiak, I. Vinnychuk, "Sectoral Analysis of Environmental Economics: The View from Ukraine", Scientific Annals of Economics and Business, 66(3), pp. 321-334, 2019.

[43] S. D. Oliner \& D. E. Sichel, "The resurgence of growth in the late 1990s: Is information technology the story?", Journal of Economic Perspectives, 14(4), pp. 3-22, 2000. http://doi.org/10.1257/jep.14.4.3

[44] D. W. Jorgenson, \& K. J. Stiroh, "Raising the speed limit: U.S. economic growth in the information age", Brookings Papers on Economic Activity, 31(2000-1), pp. 125-236, 2000. https://doi.org/10.1787/561481176503

[45] J. Jalava \& M. Pohjola, "Economic growth in the new economy: Evidence from advanced economies", Information Economics and Policy, 14(2), pp. 189-210, 2002.

[46] P. Schreyer, "The Contribution of Information and Communication Technology to Output Growth: A Study of the G7 Countries", Working Paper, OECD Science, Technology and Industry, 2000/2, OECD Publishing, 2000. https://doi.org/10.1787/151634666253

[47] F. Daveri, "Is Growth an ICT-story in Europe too?", IGIER Working Paper, 168, 2020. http://dx.doi.org/10.2139/ssrn.249115

[48] B. Van ark, J. Melka, N. Mulder, M. Timmer \& G. Ypma, "ICT Investment and Growth Accounts for the European Union, 1980-2000", Final Report, [in:] ICT and Growth Accounting, for the DG Economics and Finance of the European Commission, Brussels, $2002 . \quad$ URL: https://pure.rug.n1/ws/portalfiles/portal/306078 8/GD-56.pdf

[49] S. Dewan \& K. L. Kraemer, "Information technology and productivity: Preliminary evidence from country-level data", Management Science, 46(4), pp. 548-562, 2000.

https://doi.org/10.1287/mnsc.46.4.548.12057

[50] S.T. Lee, R. Gholami \& T.Y. Tong, "Time series analysis in the assessment of ICT impact at the aggregate level-Lessons and implications for the new economy", Information and Management, 42(7), pp. 1009-1022, 2005. https://doi.org/10.1016/j.im.2004.11.005

[51] H. Edquist, "The Swedish ICT miracle-Myth or reality?", Information Economics and Policy, 17(3), pp. 275-301, 2005. https://doi.org/10.1016/j.infoecopol.2004.06.00 4

[52] Antonelli C., "The diffusion of advanced telecommunications in developing countries", Organization for Economic Cooperation and Development (OECD), Paris, 1991.

[53] G. Madden \& S.J. Savage, "CEE telecommunications investment and economic growth", Information Economics and Policy, 10(2), pp. 173-195, 1998. https://doi.org/10.1016/S0167-6245(97)000206 
[54] L. H. Roller \& L. Waverman, "Telecommunications infrastructure and economic development, a simultaneous equations approach", American Economic Review, 91(4), pp. 909-923, 2001. https://doi.org/10.1257/aer.91.4.909

[55] M. Dubyna, A. Zhavoronok, N. Kudlaieva \& I. Lopashchuk, "Transformation of household credit behavior in the conditions of digitalization of the financial services market", Journal of Optimization in Industrial Engineering, 14(1), pp. 97-102, 2021.

[56] N. Kholiavko, L. Popova, M. Marych, I. Hanzhurenko, S. Koliadenko, \& V. Nitsenko, "Comprehensive methodological approach to estimating the research component influence on the information economy development", Naukovyi Visnyk Natsionalnoho Hirnychoho Universytetu, (4), pp. 192-199, 2020.

[57] O. Lagovska, V. Ilin, M. Kotsupatriy, M. Ishchenko, \& L. Verbivska, "Priority directions of tax policy change in the information sphere", Naukovyi Visnyk Natsionalnoho Hirnychoho Universytetu, 3, pp. 183-190, 2020. https://doi.org/10.33271/nvngu/2020-3/183

[58] I. Oliychenko, S. Shkarlet, M. Dubyna, M. Ditkovska \& V. Zhovtok, "Comparative analysis of best practices in e-Government implementation and use of this experience by developing countries", Administratie si Management Public, 34, pp. 118-136, 2020. https://doi.org/10.24818/amp/2020.34-07

[59] K. F. L. Jacobsen "Telecommunications - a means to economic growth in developing countries?", CMI report, Chr. Michelsen Institute, Bergen, Norway, 2003.

[60] L. Waverman, M. Meschi, \& M. Fuss, "The Impact of Telecoms on Economic Growth in Developing Countries", Vodafone Policy Paper Series, 2, pp. 10-24, 2005.

[61] P. Koutroumpis, "The economic impact of broadband on growth: A simultaneous approach", Telecommunications Policy, 33(9), pp. 471-485, 2009.

[62] Ye. Polishchuk, S. Onikiienko, A. Ivashchenko, A. Kornyliuk, \& N. Demchyshak, "Prior credit assessment of long-term SME projects with non-standard cash flows", Banks and Bank Systems, 16(2), pp. 148-158, 2021. https://doi.org/10.21511/bbs.16(2).2021.14

[63] O. Popelo, S. Tulchynska, O. Garafonova, L. Kovalska \& S. Khanin, "Methodical approach to assessing innovative development efficiency of regional economic systems in the conditions of the creative economy development", WSEAS transactions on environment and development, 17, pp. 685-695, 2021. https://doi.org/10.37394/232015.2021.17.66

[64] O. Popelo, S. Tulchynska, V. Marhasova, O. Garafonova \& Y. Kharchenko, "Public management of regional development in the conditions of the inclusive economy formation", Journal of Management Information and Decision Sciences, 24(7), pp. $1-8,2021$.

[65] O. Popelo, S. Tulchynska, V. Marhasova, N. Ivanova \& H. Samiilenko, "An innovative approach to determine the sustainable development of regions by harmonization of the economic, social and environmental components", Journal of Management Information and Decision Sciences, 24(8), pp. 1-9, 2021. https://doi.org/1532-5806-24-8-340

[66] H. J. Seo, Y.S. Lee, J.H. Oh, "Does ICT investment widen the growth gap?", Telecommunications Policy, 33, pp. 422-431, 2009.

[67] S. Shkarlet, M. Dubyna, K. Shtyrkhun, L. Verbivska, "Transformation of the Paradigm of the Economic Entities Development in Digital Economy", WSEAS Transactions on Environment and Development, 16, pp. 413422, 2020.

[68] O. Pasko, I. Balla, I. Levytska, N. Semenyshena, "Accountability on Sustainability in Central and Eastern Europe: An Empirical Assessment of SustainabilityRelated Assurance", Comparative Economic Research. Central and Eastern Europe, 24(3), pp. 27-52, 2021. https://doi.org/10.18778/1508-2008.24.20

[69] M. Voronenko, D. Nikytenko, J. Krejci, N. Savina, V. Lytvynenko, "Assessing the possibility of a country's economic growth using static Bayesian network models", CEUR Workshop Proceedingsthis, 2608, pp. 462-473, 2020.

[70] O. Mykytiuk, Z. Varnalii, D. Nikytenko, S. Gedek, L. Pashnyuk, "Investment determinants of economic growth: World experience and Ukraine", Intellectual Economicsthis, 2020, 14(2), pp. 106-123, 2020.

[71] V. Lytvynenko, D. Nikytenko, M. Voronenko, N. Savina, O. Naumov, "Assessing the Possibility of a Country's Economic Growth Using Dynamic Bayesian Network Models", International Scientific and Technical Conference on Computer Sciences and Information Technologies, 1, 9321995, pp. 3639, 2020. 
[72] Brent. H. Meyer, Prescott Brian, Xuguang Simon Sheng, "The Impact of the COVID-19 Pandemic on Business Expectations", International Journal of Forecasting, 2020. https://doi.org/10.1016/j.ijforecast.2021.02.00

[73] C. E. Grigoraș-Ichim, C. G. Cosmulese, D. Savchuk, \& A. Zhavoronok, "Shaping the perception and vision of economic operators from the Romania - Ukraine - Moldova border area on interim financial reporting", Economic Annals-XXI, 173(9-10), pp. 60-67, 2018. https://doi.org/10.21003/ea.V173-10

[74] Prince Asare Vitenu-Sackey, Richard Barfi, "The Impact of Covid-19 Pandemic on the Global Economy: Emphasis on Poverty Alleviation and Economic Growth", The Economics and Finance Letters, Conscientia Beam, 8(1), pp. 32-43, 2021. https://doi.org/10.18488/journal.29.2021.81.32. 43

[75] S. Roy, "Economic Impact of Covid-19 Pandemic. Technical Report". A preprint, 2020. URL:

https://www.researchgate.net/publication/3432 22400 ECONOMIC IMPACT OF COVID19_PANDEMIC

[76] J. M. De Vet, D. Nigohosyan, J. Núñez Ferrer, A.-K. Gross, S. Kuehl \& M. Flickenschild, "Impacts of the COVID-19 pandemic on EU industries", Publication for the committee on Industry, Research and Energy, Policy Department for Economic, Scientific and Quality of Life Policies, European Parliament, Luxembourg.

[77] S. Markovic, N. Koporcic, M. ArslanagicKalajdzic, S. Kadic-Maglajlic, M. Bagherzadeh \& N. Islam, "Business-to-business open innovation: COVID-19 lessons for small and medium-sized enterprises from emerging markets", Technological Forecasting and Social Change, 170, 120883, 2021. https://doi.org/10.1016/j.techfore.2021.12088

[78] C. Evans, "The coronavirus crisis and the technology sector", Business Economics, 55, 253-266, 2020. https://doi.org/10.1057/s11369020-00191-3

\section{Creative Commons Attribution License 4.0 (Attribution 4.0 International, CC BY 4.0)}

This article is published under the terms of the Creative Commons Attribution License 4.0 https://creativecommons.org/licenses/by/4.0/deed.e $\underline{n}$ US 